\title{
Hydrological and Sediment Transport Simulation to Assess the Impact of Dam Construction in the Mekong River Main Channel
}

\author{
${ }^{1}$ Satoshi Kameyama, ${ }^{1}$ Hiroto Shimazaki, \\ ${ }^{1}$ Seiichi Nohara, ${ }^{2}$ Tatsuaki Sato, ${ }^{2}$ Yoshiaki Fujii and ${ }^{2}$ Keita Kudo \\ ${ }^{1}$ National Institute for Environmental Studies, Asian Environmental Research Group, \\ Watershed Ecosystem Section, Onogawa 16-2, Tsukuba City, Ibaraki 305-8506, Japan \\ ${ }^{2}$ Alpha Hydraulic Engineering Consultants Co. Ltd, \\ Hassamu 9-14, Nishi-ku, Sapporo City, Hokkaido 063-0829, Japan
}

Received 2011-07-16, Revised 2012-01-12; Accepted 2013-06-29

\begin{abstract}
The downstream impact of dams is a complex problem in watershed management. In the upper Mekong River watershed and its main channel, dam construction projects were started in the 1950s to meet increasing demands for energy and food production. Dams called the Mekong Cascade were completed on the Mekong River in China, the Manwan Dam in 1996 and the Dachaoshan Dam in 2003. We evaluated the impact of the Manwan Dam and its related watershed development on seasonal water discharge and suspended sediment transportation using hydrological simulations of target years 1991 (before dam construction) and 2002 (after dam completion). Our study area was the main channel of the Mekong River in northern Thailand extending about $100 \mathrm{~km}$ downstream from the intersection of Myanmar, Thailand and Laos. We used the MIKE SHE and MIKE11 (Enterprise) models to calculate seasonal changes of water discharge and sediment transport at five points $15-35-\mathrm{km}$ apart in this interval. Sediment load was calculated from a regression equation between sediment load and water discharge, using suspended sediment concentrations in monthly river water samples taken between November 2007 and November 2008. Finally we estimated annual sediment load along the study reach using from both of simulated annual hydrograph and the regression equation. Our simulations showed that after construction of the dam, there was a moderate decrease in peak discharge volume and during the rainy season in August and September and a corresponding increase in the subsequent months. Accordingly, sediment transportation budgets were increased in months after the rainy season. The suspended sediment transportation in Chiang Sean was increased from 21.13 to 27.90 ( $\mathrm{M}$ ton/year) in our model condition.
\end{abstract}

Keywords: Mekong River, Manwan Dam, Seasonal Hydrological Dynamics, MIKE SHE, MIKE11, Suspended Sediment Transportation

\section{INTRODUCTION}

The Mekong River (called the Lancang River in China) is the largest international river in East Asia, with a watershed area of $795,000 \mathrm{~km}^{2}$ and a main channel $4800 \mathrm{~km}$ long. Its watershed includes parts of six countries: China, Myanmar, Laos, Viet Nam, Thailand and Cambodia. Within this watershed, traditional social and industrial activities have long been conducted in harmony with the ecological services associated with the Mekong River (Hudson-Rodd and Shaw, 2003; Ringler and Cai, 2006). In recent years, however, Watershed Ecosystem Section, Onogawa 16-2, Tsukuba City, Ibaraki 305-8506, Japan 
demands for electric power and water resources have been increasing to meet rapid population growth and economic development (Dore and Lebel, 2010; Dudgeon, 2005) and large-scale watershed development, including dam construction and land use changes, has affected many parts of the watershed (Adamson, 2001; Bai et al., 2009; Baran and Myschowoda, 2009; Brown and McClanahan, 1996).

One of the most ambitious projects is the set of hydropower dams in China called the Mekong Cascade (He et al., 2006; Wei et al., 2009). Of these, the Manwan Dam was completed in 1996 and the Dachaoshan Dam was completed in 2003. Six more dams are under construction or in the planning stage. These dams are the first constructions in history to have blocked the Mekong River (Hu et al., 2009; Zhai et al., 2010). The social impacts and the effects on watershed ecosystems downstream of these dams as transboundary environmental issues has brought international attention (Bai et al., 2009; Cui et al., 2007; Tilt et al., 2009; Wei et al., 2007; Webby et al., 2007).

Dam construction has some positive impacts, such as electricity production, management of water resources and flood control (McNally et al., 2009). However, upstream control of water discharge can negatively affect traditional agricultural systems and fisheries (Dugan et al., 2010; Kang et al., 2009a; 2009 b) as a result of drastic changes in water volume (Cheng et al., 2005; 2008; Li et al., 2006; Li and He, 2008) and sediment movement (Chen and Zhao, 2001; Fu et al., 2006; 2008; Fu and He, 2007; Kummu et al., 2010). The traditional lifestyles of local people living downstream of the dams are dependent on the natural and seasonal hydrologic dynamics of the Mekong River (Costa-Cabral et al., 2008; Quang and Nguyen, 2003). Upstream control of water discharge can cause degradation of freshwater fish habitat and bank erosion in agricultural lands (Wang et al., 2007; Wood et al., 2008). Similarly, seasonal flooding is an essential part of the watershed ecosystem (Kummu and Sarkkula, 2008; Kummu and Varis, 2007; Larmberts and Koponen, 2008).

To aid understanding of these watershed environmental issues, we carried out a study with the following objectives:

- To undertake hydrological simulations in the upper Mekong watershed to quantify the impact of watershed development, including Manwan Dam construction

- To model watershed conditions in 1991 (before dam construction) and 2002 (dam completed). We used 2002 precipitation data as input to these runoff models to isolate the impacts from watershed alteration
- To focus on the changes in annual water discharge (seasonal hydrologic regime) and sediment transportation resulting from watershed development

Our study area covered the part of the Mekong River main channel that extends about $100 \mathrm{~km}$ downstream from the junction of the borders of Myanmar, Thailand and Laos (the Golden Triangle). We selected five data validation points at approximately $15-35-\mathrm{km}$ intervals along this section of the river and calculated model parameters every $1 \mathrm{~km}$.

Watershed structural parameters were determined from field measurements and GIS/remote sensing methodology. Other hydrological parameters in the model were determined from river monitoring data, including water level and precipitation provided by the Mekong River Commission (MRC). To validate our simulated results, we surveyed the target reach to acquire field data on the surface water elevation and water discharge. To determine the relationship between water discharge and sediment load, we analyzed the turbidity of river water samples collected in the study region each month between November 2007 and May 2010.

\section{MATERIALS AND METHODS}

Study area: In the upper Mekong watershed, we set up a model with two catchment areas above Luang Prabang, the capital of Laos (Fig. 1). The uppermost catchment, watershed a colored with light green, has its outlet at Chiang Sean, located approximately $10 \mathrm{~km}$ downstream from the Golden Triangle where Myanmar, Laos and Thailand meet. Its area is 194,015 $\mathrm{km}^{2}$, representing $24.4 \%$ of the whole Mekong River watershed. The second catchment, watershed $\mathrm{B}$ with light blue, lies between watershed A and Luang Prabang. Its area is $83,226 \mathrm{~km}^{2}$, representing $10.5 \%$ of the Mekong River watershed. In both watersheds, we performed simulations that included a distributed watershed model and a one-dimensional hydrological model. In addition, we carried out a suspended sediment transport simulation for the Mekong River main channel in the upper region of watershed B from Chiang Sean to Chiang Khong. Watershed A includes mountainous areas of the southeastern Tibetan Plateau and watershed B consists of a broad flood plain and relatively gentle agricultural lands along the river banks.

The Mekong Cascade is under construction in the middle part of watershed A (Keskinen, 2008). The Manwan Dam, the first dam to be constructed (MRC, 2009), is located in Yunnan province of China about 746 $\mathrm{km}$ upstream from Chiang Sean and was constructed from 1986 to 1993 (Zhai et al., 2007). The hydropower station commenced operation in June 1996. 


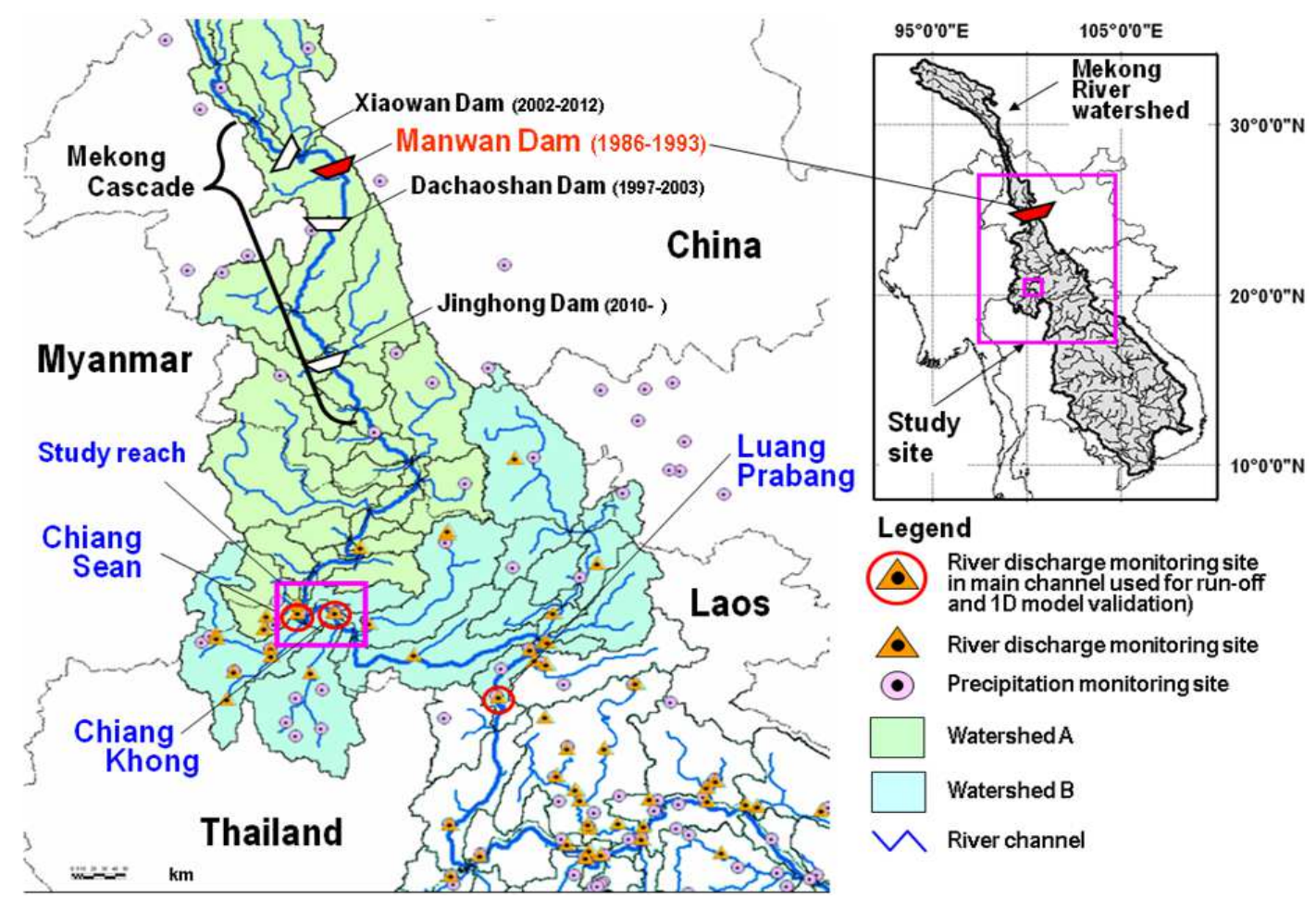

Fig. 1. Map showing the Mekong River watershed, discharge and precipitation monitoring sites and location of the study region (pink colored rectangle)

The catchment area above the Manwan Dam site is $114500 \mathrm{~km}^{2}$. The Manwan reservoir has a total storage capacity of $1006 \times 10^{6} \mathrm{~m}^{3}$ and an effective storage of $257 \times 10^{6} \mathrm{~m}^{3}$. Its normal water level is $994.00 \mathrm{~m}$, with a corresponding storage of $920 \times 10^{6} \mathrm{~m}^{3}$. Its dead water level is $982 \mathrm{~m}$ and will be $988 \mathrm{~m}$ after the completion of the Xiaowan hydropower station immediately upstream Manwan Hydropower Station Home Page.

Since completion of the Manwan Dam, the Dachaoshan Dam was completed from 1997 to 2003 and the Xiaowan Dam (2002-2012) and Jinghong Dam (2010) are currently in progress. When the Mekong Cascade is fully built, this area will have 8 dams.

\subsection{Study Flow}

A flow chart showing the structure of our study is shown in Fig. 2. The purpose of this study was to estimate the annual hydrologic dynamics and suspended sediment transport before and after Manwan Dam construction, using 1991 (before dam construction) and 2002 (after dam construction) as target simulation years.

In the first step, we determined watershed model parameters for the two target years. We used actual daily precipitation data in watershed $\mathrm{A}$ and water discharge/level data at the Chiang Sean monitoring site for each year. Next, we used the historical daily 2002 precipitation data as input into both of the 1991 and 2002 watershed model in watershed A. Then we compared the resulting annual hydrographs of both years at Chiang Sean. By comparing the two hydrographs in Chiang Sean, one "hypothetical virtual 2002 simulation = If no Manwan dam" and the other "2002 simulation", we could directly detect the changes resulting from construction of the Manwan Dam. In the second step, we calculated the water discharge downstream in watershed B. In the simulation model, we selected watershed parameters and validated the results by using 2002 daily precipitation data, actual water level data at Chiang Sean and water discharge data at Luang Prabang.

In the third step, we estimated the values of seasonal transportation of suspended sediment (using the 1991 and 2002 watershed models and 2002 precipitation data) along the $95-\mathrm{km}$ study reach in watershed B. From this we calculated the change of hourly suspended sediment passing Chiang Sean between the two target years. 


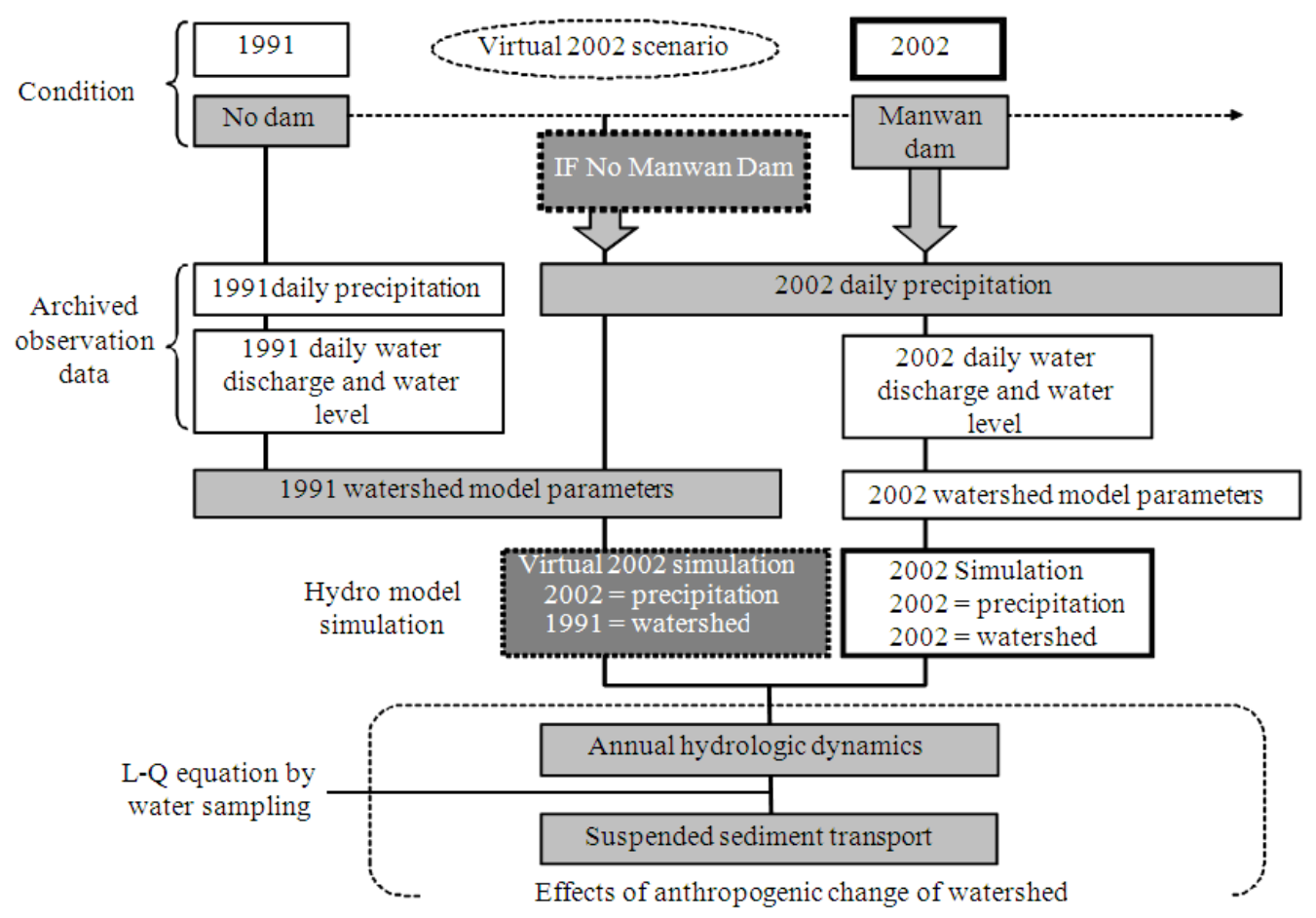

Fig. 2. Flow chart of this study

To estimate sediment transport, the L-Q equation showing the relationship between suspended sediment load and water discharge was needed. We calculated suspended sediment transport by multiplying water discharge values and sediment loads from Chiang Sean to $95-\mathrm{km}$ downstream reach. We derived the annual cycle of suspended sediment by summing the sediment values in each month of the two target years, which allowed us to measure the differences between the two years.

\subsection{L-Q Equation}

Our L-Q equation was an exponential regression equation derived from the scatter diagram of water discharge and suspended sediment at Chiang Sean from November 2007 to May 2010. The relationship of the form $\mathrm{L}=\mathrm{aQb}$ was fitted to these data using both $\log / \log$ regression and a nonlinear estimation (Solver) routine.

We determined suspended sediment concentrations in monthly water samples from Chiang Sean at our institute between November 2007 and May 2010. Water discharge data was downloaded from daily monitored water level/discharge telemetry data (MRC home page) for same period. The suspended sediment load was determined by multiply the suspended sediment concentrations by water discharge at the same time.
Finally, monthly sediment transport values were calculated by integrating these estimated hourly sediment load values.

\subsection{Hydrological Simulation Model and Parameter Optimization Algorithm}

We combined the MIKE SHE and MIKE11 (Enterprise) models, calibrated for each target watershed and simulated years, as our distributed runoff model (Danish Hydraulic Institute (DHI), MIKE SHE, MIKE 11). For numerical sub-models, we adopted twodimensional diffusive wave models for surface flow, one-dimensional dynamic wave models for stream flow and a multiple-stage tank model for underground flow. The tank model used five tanks, including three tanks for interflow reservoirs and two tanks for base flow reservoirs (Thompson et al., 2004).

As parameters for watershed A, we used daily precipitation in watershed $\mathrm{A}$ and water discharge at Chiang Sean as lower end boundary conditions. For watershed B, we used daily water discharge at Chiang Sean as the upper end boundary condition and water level at Luang Prabang as the lower end boundary condition. The simulated times were the years 1991 and 2002. Sediment transport was calculated at $1 \mathrm{~km}$ intervals every $60 \mathrm{sec}$. 
As the optimization algorithm for our watershed models, we adopted the Shuffled Complex Evolution (SCE) method (Duan et al., 1992; 1993; 1994) to decide parameter values. This is a global search method that has the advantage of determining optimum parameter values regardless of the initial values chosen (Lin et al., 2006; Madsen, 2000).

\subsection{Data Set}

All geological data including surface elevation, small catchment polygon, river channel, width/depth of the river and surface water gradient were arranged in a GIS database. Then the data described below were fed into the simulation model.

Watershed structure data were as follows. The watershed boundary and streamline data were derived from the HYDRO-1k Elevation Derivative Database USGS, EROS Center Homepage. SRTM-3 (The Shuttle Radar Topography Mission data-3 National GeospatialIntelligence Agency (NGA) and National Aeronautics and Space Administration (NASA) were used as the surface elevation model. The river edge lines used to calculate river width were derived from Google Earth imagery and GPS measurements made in the field. Data for water surface elevation and river cross sections for the model input sites were derived from our field GPS and Acoustic Doppler profiler (ADP) measurements from 2007 to 2009, respectively. The ADP data were also used as model calibration data in each calculation point.

For 1991 and 2002 precipitation data, we used the "Rainfall data of China" provided by the Climatic Data Center, National Meteorological Information Center, China Meteorological Administration (China meteorological data sharing service system Homepage) and "Precipitation Amount" of The National Oceanic and Atmospheric Administration (NOAA), National Centers for Environmental Prediction (NCEP) Automated Data Processing (ADP) operational global synoptic surface data NOAA, National Centers for Environmental Prediction Homepage.

We divided our study area into Thiessen polygons based on precipitation monitoring sites.

For water level and water discharge data for 1991 and 2002, we used MRC Hydro Year Book recorded data for each calibration or validation point in the model. For water discharge data at Chiang Sean from November 2007 to December 2008, we downloaded daily water levels from the Chiang Sean water level telemetry monitoring website Mekong River Commission Water level homepage, then converted it into water discharge using the station's water level-water discharge equation.
For suspended sediment concentrations, we analyzed the concentration of suspended sediment by micro filtration of monthly river water samples taken at check points of the watershed model.

\section{RESULTS AND DISCUSSION}

Hydro simulation in 1991 and 2002 in Chiang Sean: The annual hydrographs at Chiang Sean in 1991 and 2002, both actual and modeled, are shown in Fig. 3a and b. The annual flow regime consisted of a high-water period in the rainy season, from the end of June to September and a low-water period in the winter dry season. The observed peak discharge was about 13,000 $\mathrm{m}^{3} \mathrm{sec}^{-1}$ in each year and the minimum level was approximately $1000-1200 \mathrm{~m}^{3} \mathrm{sec}^{-1}$. Therefore the flow regime coefficient (ratio of maximum to minimum stream discharge) was about 10.8 to 13.0 in the region upstream from Chiang Sean.

The simulated discharge of 2002 better reproduced the observed discharge throughout the year than the 1991 simulation. In the 1991 simulation, the water discharges from July to August were below the observed discharge peaks. We attribute this to the modulating effect of very small tributaries in the small catchments. The period of decreasing flow was delayed from September to October in the 1991 hydrograph, which we attribute to a prolonged rainy season that year. Through these simulations, we adjusted model parameters for the two periods. Those decided watershed parameters and its values were shown in Table 1. The most changed parameter values of the model were interflow time constant (from 55.79 to 115.5 ) and reservoir 1 time constant for base flow (from 58.3 to 212.0) in our model.

\subsection{Change of Water Discharge from Dam Construction}

We simulated the annual runoff process to the study watershed using the 1991 and 2002 watershed models under same 2002 precipitation (Fig. 4). The difference of the two hydrographs (black bold line and gray bold line) is the effect of structural changes in the watershed that included dam construction. The black thin line is the observed water discharge data in Chiang Sean.

In the whole year, simulated water discharge varied from approximately 1000 to $9000-10500 \mathrm{~m}^{3} \mathrm{sec}^{-1}$. In the months after the last discharge peak, discharge in the virtual 2002 simulation (1991 watershed model with 2002 precipitation) was larger than in the 2002 simulation by about 1000 to $1500 \mathrm{~m}^{3} \mathrm{sec}^{-1}$. We interpret the difference in water discharge during the receding phase as a delay in the reduction of flow because of the landuse change and some modulating effect of the dam. 
Satoshi Kameyama et al. / American Journal of Environmental Science 9 (3): 247-258, 2013

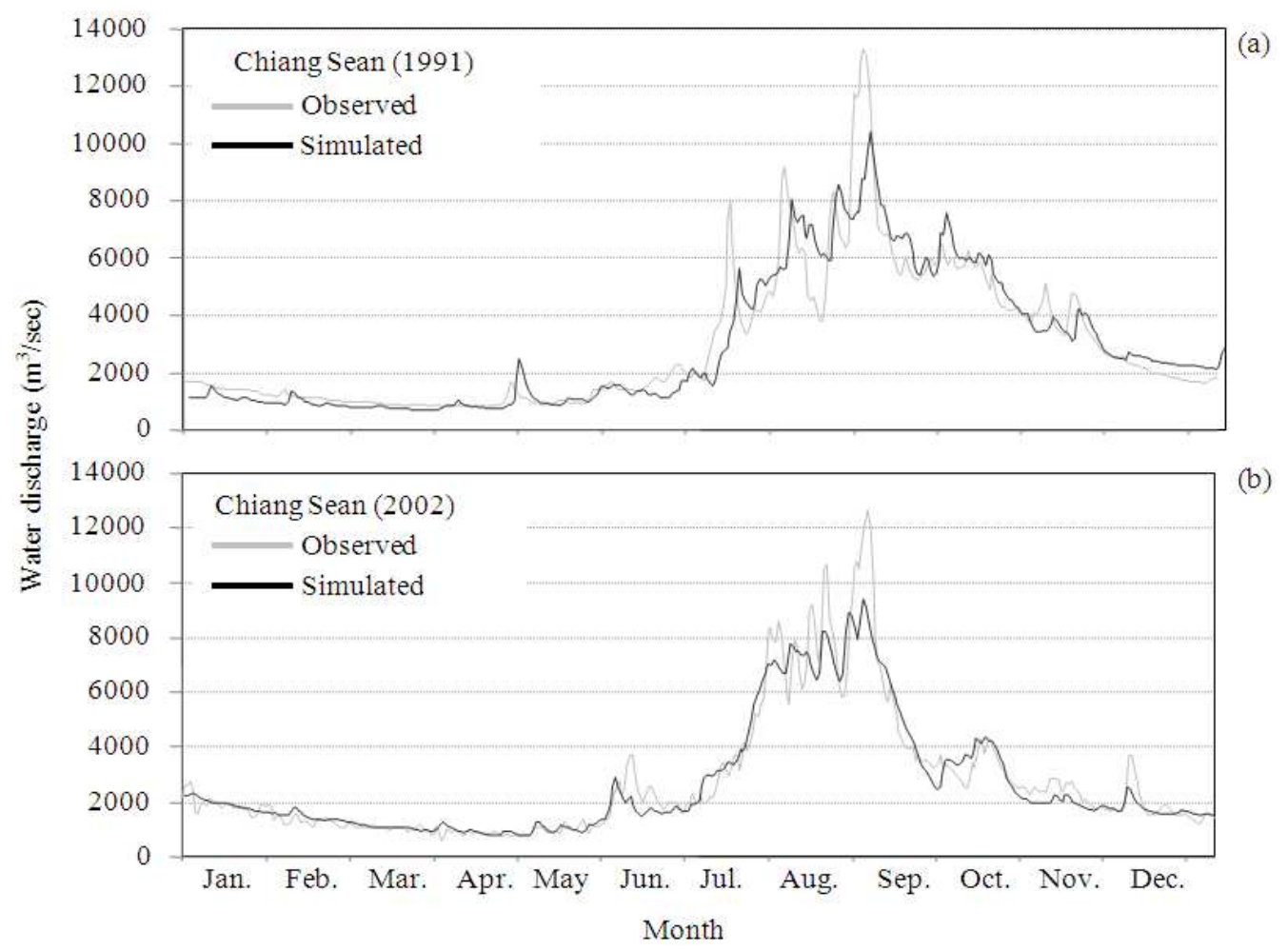

Fig. 3. Annual hydrographs at Chiang Sean monitoring site in (a) 1991 and (b) 2002. The black line and gray line represent actual observed data and simulated data, respectively

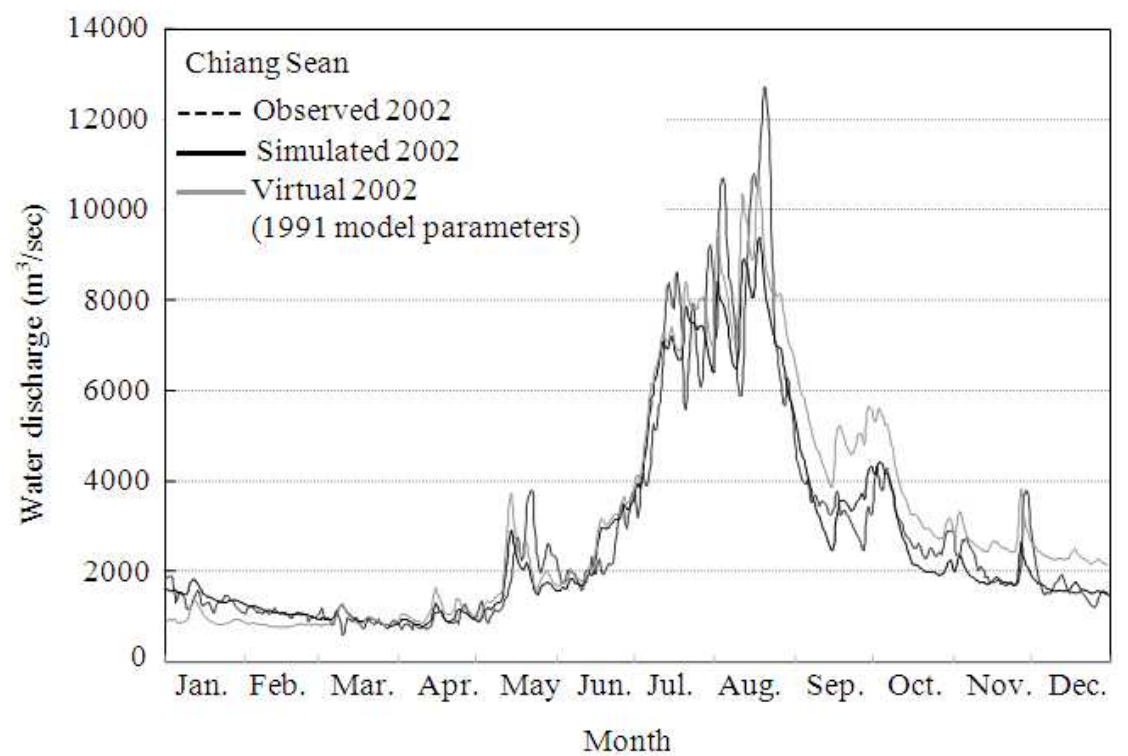

Fig. 4. Hydrographs at Chiang Sean. The thin black line is the observed hydrograph in 2002, the bold black line is the simulated 2002 hydrograph and the bold gray line is a virtual 2002 hydrograph generated by combining 2002 precipitation data with the 1991 watershed model 


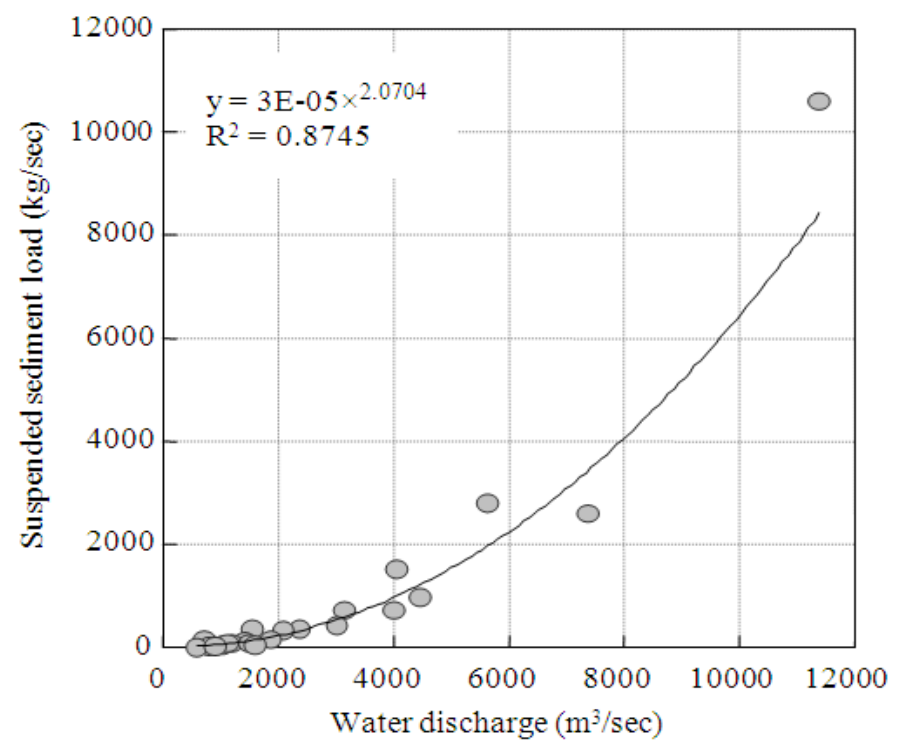

Fig. 5. Relationship between water discharge and suspended sediment load at Chiang Sean monitoring site based on the turbidity of river water samples

Table 1. The model parameters and its values adapted to watershed $\mathrm{A}$

\begin{tabular}{llrr}
\hline Sub-model & Parameter name & 2002 simulation & Virtual 2002 simulation \\
\hline Precipitation & Net Rainfall Fraction & 0.69 & 0.87 \\
& Infiltration Fraction & 0.68 & 0.67 \\
Interflow reservoir & Specific Yield & 0.30 & 0.23 \\
& Percolation Time Constant & 318.30 & 350.40 \\
& Interflow Threshold Depth & 0.64 & 0.50 \\
& Interflow Time Constant & 55.79 & 115.50 \\
& Reservoir 1 Specific Yield & 0.34 & 0.34 \\
Base flow reservoir & Reservoir 1 Time Constant for Base flow & 58.30 & 212.00 \\
& Reservoir 1 Dead Storage Fraction & 0.48 & 0.30 \\
& Reservoir 1 Threshold Depth for Base flow & 0.26 & 0.82 \\
& Reservoir 2 Specific Yield & 0.33 & 0.40 \\
& Reservoir 2 Time Constant for Base flow & 165.70 & 133.20 \\
& Reservoir 2 Dead Storage Fraction & 0.28 & 0.37 \\
& Reservoir 2 Threshold Depth for Base flow & 0.71 & 0.63 \\
& Fraction of Percolation to reservoir 1 & 0.53 & 0.48 \\
\hline
\end{tabular}

\subsection{L-Q Equation at Chang Sean}

Figure 5 shows the relationship between water discharge and suspended sediment load at Chang Sean from November 2007 to December 2008. We fitted an L$\mathrm{Q}$ equation to these data, expressing the correlation between suspended sediment load $(\mathrm{kg} / \mathrm{s})$ and water discharge $\left(\mathrm{m}^{3} / \mathrm{s}\right)$, as follows:

$$
y=0.00003 x^{2.0704}\left(R^{2}=0.87\right)
$$

We used this equation to convert water discharge values to suspended sediment loads throughout the year. The maximum sediment concentration was recorded during the unusually great August 2008 floods, when the estimated sediment budget was approximately $10613 \mathrm{~kg} \mathrm{sec}{ }^{-1}$. In this monitoring period, the sediment load was less than $3000 \mathrm{~kg} \mathrm{sec}^{-1}$ without the maximum case in August 2008.

\subsection{Change of Monthly Sediment Transport in Chiang Sean}

Figure 6 shows the seasonal change of suspended sediment load at Chiang Sean for the 2002 and 1991 watershed models under 2002 precipitation. The 
sediment load ranged from $200 \times 10^{3}$ tons month $^{-1}$ to $8800-11200 \times 10^{3}$ tons month ${ }^{-1}$. The trend in sediment load is similar to that of water discharge, given that the sediment concentration and water discharge have a correlative relationship. The difference between the two models is notably large from August to December. Whereas the difference in water discharge could be attributed to the delay of the post-rainy season recession after dam construction and landuse change, the monthly sediment transportation from August to December decreased to about $40 \%$ of its former value. We estimated that the decrease in sediment transportation amounted to a total of approximately $6000 \times 10^{3}$ tons in the post-rainy season period. We considered the difference of sediment transportation that has similar causes of seasonal hydrograph.

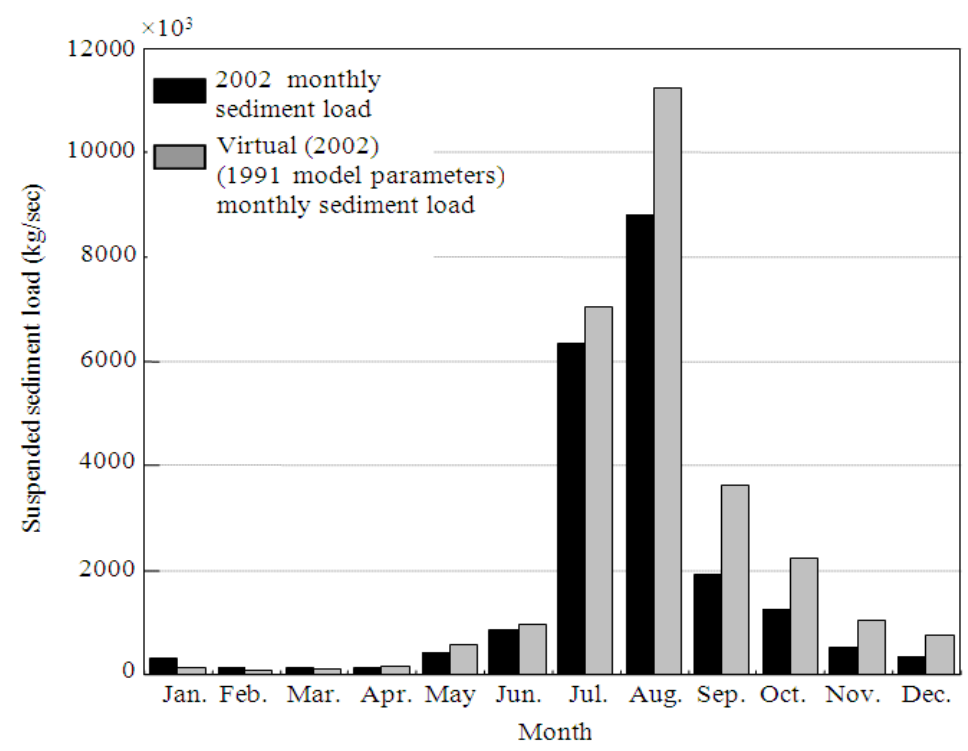

Fig. 6. Comparison of seasonal dynamics of suspended sediment load at Chiang Sean. The black and gray bars indicate the loads calculated from the 2002 and virtual 2002 hydrographs (1991 parameter model), respectively

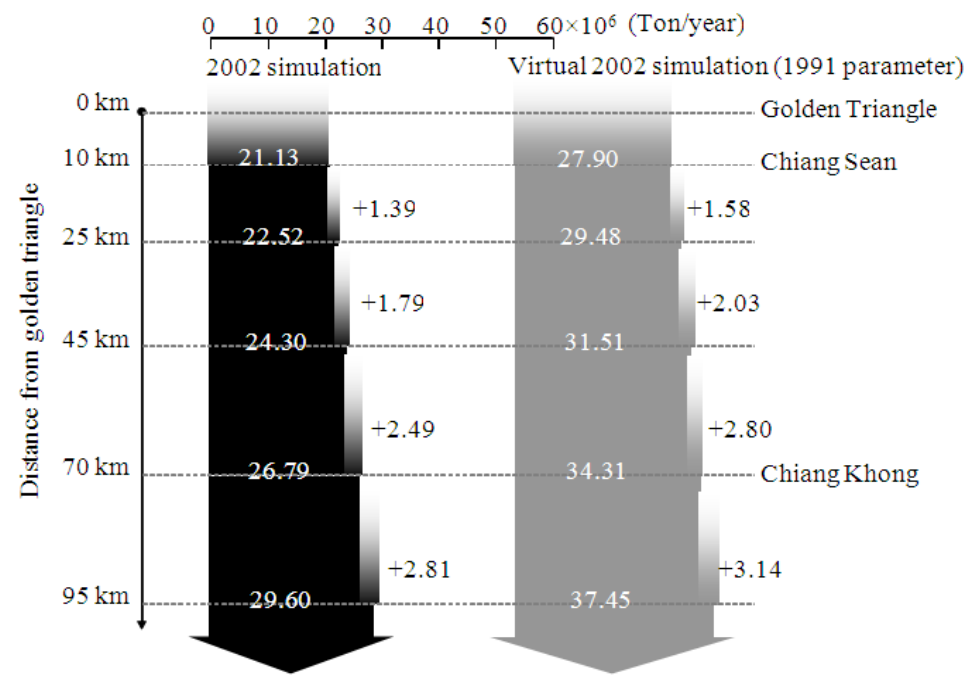

Fig. 7. Suspended sediment budget in the study site from the golden triangle to the Laos border. Black and gray arrows are results for simulations of the 2002 and virtual 2002 hydrographs (1991 parameter model), respectively. The widths at each station represent the volume of sediment transport and the increments represent inputs of sediment at each calibration station along the target reach. The values on the side of the arrows are the changes of suspended sediment budget 


\subsection{Change of Annual Sediment Budgets in the Study Reach}

Figure 7 shows the sediment transport loads and their changes downstream in the $95-\mathrm{km}$ study reach from near Chiang Sean to the Thailand-Laos border beyond Chiang Khong (Fig. 1(left), pink colored box of study reach). The annual sediment transport volumes at Chiang Sean were $27.90 \times 10^{6}$ tons year $^{-1}$ in

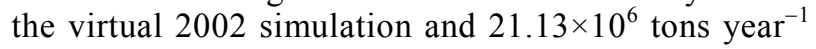
in the 2002 simulation. The estimated sediment transport value of the 2002 simulation is reasonable to other monitoring results. The MRC annual sediment transport data in Gajiu station located about $2 \mathrm{~km}$ downstream the Manwan dam showed approximately $22 \times 10^{6}$ tons year $^{-1}$ in the 2002 (Fu et al., 2008). Lu and Siew (2006) reported that mean sediment flux in Chiang Sean was $34.5 \times 10^{6}$ tons year ${ }^{-1}$ from 1993 to 2000 . A slight error of our estimated suspended load to another study results was caused primarily by the underestimation of peak water discharge.

At successive check points downstream, the transport volume increased in both simulations. Comparing watersheds before and after dam construction, the estimated annual sediment transport volume at Chiang Sean decreased approximately $24.27 \%$ between 1991 parameters and 2002 parameters.

Our model considered differences in the sediment budget due to both dam construction and overall watershed development, including land-use changes and channelization of tributaries in the upper catchment. However, the main reason for decreasing of annual sediment transport volume was the effect of water discharge changes in the months after the rainy season. The delay and prolongation of this period of declining discharge was directly related to the sediment transport regime.

This relationship implies that the operations of the lowest dam in the Mekong Cascade are the most critical for the seasonal hydrodynamics of river water and sediment movement immediately downstream.

In our study to the Mekong watershed, it was clear that the Manwan Dam construction and the surrounding development are key factors in changing the seasonal hydrodynamics and suspended sediment transportation. To prevent considerable impact of large Dam, beforeafter assessment of sediment transport regime and long term hydrological monitoring are essential.

\section{CONCLUSION}

This study was intended to help assess the impact of dam construction on the seasonal hydrologic regime and sediment transportation in the Mekong River main channel by using a watershed runoff model simulation. The target years were 1991 and 2002, before and after construction of the Manwan Dam and the target river reach extended about $100 \mathrm{~km}$ downstream from the Golden Triangle. Our study reached the following conclusions:

- Two watershed models were compiled, comprising a 1991 watershed (with no dam) and the 2002 watershed (after dam construction) and simulated the annual runoff and sediment transport. To evaluate of anthropogenic watershed change, we input 2002 precipitation records into two watershed models

- Based on field data and GIS analyses, optimum watershed model parameters were selected by using the SCE method. The calculated annual hydrographs for 1991 and 2002 were validated using historic data

- The simulated hydrographs before (virtual 1991) and after (2002) dam construction simulations showed that after construction of the dam, there was a moderate decrease in discharge volume in the postrainy season months from August to December

- The equation relating water discharge and suspended sediment load volume at Chiang Sean was derived as, $\mathrm{y}=0.00005 \mathrm{x}^{2.0704}\left(\mathrm{R}^{2}=0.9367\right)$, on the basis of monthly river water samples

- Monthly estimates of sediment transport at Chiang Sean for the two target years showed that the sediment volume in the post-rainy season months in the 2002 watershed had increased compared to the 1991 watershed

- The study approach, using the same year's precipitation into different watershed models, demonstrates that hydrological simulation models can assist scenario analyses for predicting the downstream impacts of planned dam construction

\section{ACKNOWLEDGEMENT}

We are grateful to associate professor Dr. Tuantong Jutagate and lecturer Mr. Chaiwut Grudpan of Ubon Rajathanee University for their suggestions and discussion of the environmental background of the study area. Mr. Aria Rattanawichaikul kindly provided help during the field survey. The climatological data was furnished from Dr. Qinxue WANG (chief of Asian Water Environment Section) at NIES. We are also grateful to Mrs. Toshiko Tsuji, a research assistant at NIES for help with digital data management. 


\section{REFERENCES}

Adamson, P., 2001. Hydrological perspectives on the lower Mekong basin the potential impacts of hydropower developments in Yunnan on the hydrology of the lower Mekong. Int. Water Power Dam Construct., 53: 16-21.

Bai, J., B. Cui, X. Xu, Q. Ding and H. Gao, 2009. Heavy metal contamination in riverine soils upstream and downstream of a hydroelectric dam on the lancang river, China. Environ. Eng. Sci., 26: 941-946. DOI: 10.1089/ees.2008.0136

Baran, E. and C. Myschowoda, 2009. Dams and fisheries in the Mekong Basin. Aquatic Ecosyst. Health Manage., 12: 227-234. DOI: 10.1080/14634980903149902

Brown, M.T. and T.R. McClanahan, 1996. E. Mergy analysis perspectives of Thailand and Mekong River dam proposals. Ecol. Modell., 91: 105-130. DOI: 10.1016/0304-3800(95)00183-2

Chen, Z. and Y. Zhao, 2001. Impact on the Yangtze (Changjiang) Estuary from its drainage basin: Sediment load and discharge. Chinese Sci. Bull., 46: 73-80. DOI: 10.1007/BF03187240 1

Cheng, C.T., J.X. Xie, K.W. Chau and M. Layeghifard, 2008. A new indirect multi-step-ahead prediction model for a long-term hydrologic prediction. J. Hydrol., 361: 118-130. DOI: 10.1016/j.jhydrol.2008.07.040

Cheng, C.T., J.Y. Lin, Y.G. Sun and K.W. Chau, 2005. Long-Term Prediction of Discharges in Manwan Hydropower Using Adaptive-Network-Based Fuzzy Inference Systems Models. In: Advances in Natural Computation, Wang, L., K. Chen and Y.S. Ong (Eds.), Springer, Berlin, ISBN-10: 3540283234, pp: 1152-1161.

Costa-Cabral, M.C., J.E. Richey, G. Goteti, D.P. Lettenmaier and C. Feldkotter et al., 2008. Landscape structure and use, climate and water movement in the Mekong River basin. Hydrol. Proc., 22: 1731-1746. DOI: 10.1002/hyp.6740

Cui, B.S., B. Hu, H.J. Zhai, G.L. Wei and J. Wang, 2007. Study on the interaction between engineering construction and ecosystem changes in the longitudinal range-gorge region. Chinese Sci. Bull., 52: 21-32. DOI: 10.1007/s11434-0077003-7
Dore, J. and L. Lebel, 2010. Deliberation and scale in Mekong region water governance. Environ. Manage., 46: 60-80. DOI: 10.1007/s00267-0109527-x

Duan, Q., S. Sorooshian and V. Gupta, 1992. Effective and efficient global optimization for conceptual rainfall-runoff models. Water Resour. Res., 28: 1015-1031. DOI: 10.1029/91WR02985

Duan, Q., S. Sorooshian and V.K. Gupta, 1994. Optimal use of the SCE-UA global optimization method for calibrating watershed models. J. Hydrol., 158: $265-$ 284. DOI: 1016/0022-1694(94)90057-4

Duan, Q., V.K. Gupta and S. Sorooshian, 1993. Shuffled complex evolution approach for effective and efficient global minimization. J. Optim. Theory Applic., 76: 501-521. DOI: 10.1007/BF00939380

Dudgeon, D., 2005. River rehabilitation for conservation of fish biodiversity in monsoonal Asia. Ecol. Soc., 10: $15-15$.

Dugan, P.J., C. Barlow, A.A. Agostinho, E. Baran and G.F. Cada et al., 2010. Fish migration, dams and loss of ecosystem services in the Mekong Basin. Ambio, 39: 344-348. PMID: 20799685

Fu, K.D. and D.M. He, 2007. Analysis and prediction of sediment trapping efficiencies of the reservoirs in the mainstream of the Lancang River. Chinese Sci. Bull., 52: 134-140. DOI: 10.1007/s11434007-7026-0

Fu, K.D., D.M. He and S.J. Li, 2006. Response of downstream sediment to water resource development in mainstream of the Lancang River. Chinese Sci. Bull., 51: 119-126. DOI: 10.1007/s11434-006-8119-x

Fu, K.D., D.M. He and X.X. Lu, 2008. Sedimentation in the Manwan reservoir in the Upper Mekong and its downstream impacts. Q. Int., 186: 91-99. DOI: 10.1016/j.quaint.2007.09.041

He, D., Y. Feng, S. Gan, D. Magee and W. You, 2006. Transboundary hydrological effects of hydropower dam construction on the Lancang River. Chinese Sci. Bull., 51: 16-24.

Hu, B., B.S. Cui, S.K. Dong, H.J. Zhai and Z.Y. Liu, 2009. Ecological Water Requirement (EWR) analysis of High Mountain and Steep Gorge (HMSG) river- Application to Upper LancangMekong River. Water Resour. Manage., 23: 341366. DOI: $10.1007 / \mathrm{s} 11269-008-9278-0$ 
Hudson-Rodd, N. and B.J. Shaw, 2003. Mekong River development-Whose dreams? Which visions? RWIN, 28: 268-275. DOI: 10.1080/02508060308691692

Kang, B., D. He, L. Perrett, H. Wang and W. Hu et al., 2009a. Fish and fisheries in the Upper Mekong: Current assessment of the fish community, threats and conservation. Rev. Fish Biol. Fisheries, 19: 465480. DOI: $10.1007 / \mathrm{s} 11160-009-9114-5$

Kang, B., L. Perrett, Y. Li and D. He, 2009b. Are the fish of the upper and lower Mekong interconnected? Chinese J. Oceanol. Limnol., 27: 400-407. DOI: 10.1007/s00343-009-9132-0

Keskinen, M., 2008. Water resources development and impact assessment in the Mekong Basin: Which way to go? Ambio, 37: 193-198. PMID: 18595274

Kummu, M. and J. Sarkkula, 2008. Impact of the Mekong River flow alteration on the Tonle Sap flood pulse. Ambio, 37: 185-192. PMID: 18595273

Kummu, M. and O. Varis, 2007. Sediment-related impacts due to upstream reservoir trapping, the Lower Mekong River. Geomorphology, 85: 275293. DOI: 10.1016/j.geomorph.2006.03.024

Kummu, M., X.X. Lu, J.J. Wang and O. Varis, 2010. Basin-wide sediment trapping efficiency of emerging reservoirs along the Mekong. Geomorphology, 119: 181-197. DOI: 10.1016/j.geomorph.2010.03.018

Larmberts, D. and J. Koponen, 2008. Flood pulse alterations and productivity of the Tonle Sap ecosystem: A model for impact assessment. Ambio, 37: 178-184. PMID: 18595272

$\mathrm{Li}, \mathrm{S}$. and D. He, 2008. Water level response to hydropower development in the upper Mekong River. Ambio, 37: 170-177. PMID: 18595271

Li, S.J., D.M. He and K.D. Fu, 2006. The correlations of multi-timescale characteristics of water level processes in Lancang-Mekong River. Chinese Sci. Bull., 51: 50-58. DOI: 10.1007/s11434-006-0050-7

Lin, J.Y., C.T. Cheng and K.W. Chau, 2006. Using support vector machines for long-term discharge prediction. Hydrol. Sci. J., 51: 599-612. DOI: 10.1623/hysj.51.4.599

Lu, X.X. and R.Y. Siew, 2006. Water discharge and sediment flux changes over the past decades in the Lower Mekong River: Possible impacts of the Chinese dams. Hydrol. Earth Syst. Sci., 10: 181-195. DOI: $10.5194 /$ hess-10-181-2006
Madsen, H., 2000. Automatic calibration of a conceptual rainfall-runoff model using multiple objectives. J. Hydrol., 235: 276-288. DOI: 10.1016/S00221694(00)00279-1

McNally, A., D. Magee and A.T. Wolf, 2009. Hydropower and sustainability: Resilience and vulnerability in China's power sheds. J. Environ. Manage., 90: S286-S293. DOI: 10.1016/j.jenvman.2008.07.029

MRC, 2009. IWRM-Based Basin Development Strategy for the Lower Mekong Basin. Mekong River Commission.

Quang, M. and P.E. Nguyen, 2003. Hydrologic impacts of China's Upper Mekong Dams on the lower Mekong River. Mekongriver.

Ringler, C. and X.M. Cai, 2006. Valuing fisheries and wetlands using integrated economic-hydrologic modeling-Mekong River Basin. J. Water Resour. Plann. Manage., 132: 480-487. DOI: 10.1061/(ASCE)0733-9496(2006)132:6(480)

Thompson, J.R., H.R. Sorenson, H. Gavin and A. Refsgaard, 2004. Application of the coupled MIKE SHE/MIKE 11 modelling system to a lowland wet grassland in southeast England. J. Hydrol., 293: 151-179. DOI: 10.1016/j.jhydrol.2004.01.017

Tilt, B., Y. Braun and D.M. He, 2009. Social impacts of large dam projects: A comparison of international case studies and implications for best practice. J. Environ. Manage., 90: S249-S257. DOI: 10.1016/j.jenvman.2008.07.030

Wang, J.J., X.X. Lu and Y. Zhou, 2007. Retrieval of suspended sediment concentrations in the turbid water of the Upper Yangtze River using Landsat ETM. Chinese Sci. Bull., 52: 273-280. DOI: 10.1007/s11434-007-7012-6

Webby, R.B., P.T. Adamson, J. Boland, P.G. Howlett and A.V. Metcalfe et al., 2007. The Mekongapplications of Value At Risk (VAR) and Conditional Value At Risk (CVAR) simulation to the benefits, costs and consequences of water resources development in a large river basin. Ecol. Modell., 201: 89-96. DOI: 10.1016/j.ecolmodel.2006.07.033

Wei, G., B.S. Cui, Z.F. Yang, J.H. Bai and J. Wang et al., 2007. Comparison of changes of typical river segment ecosystem service value in LRGR. Chinese Sci. Bull., 52: 262-272. DOI: 10.1007/s11434-0077029-x 
Wei, G.L., Z.F. Yang, B.S. Cui, B. Li and H. Chen et al., 2009. Impact of dam construction on water quality and water self-purification capacity of the Lancang River, China. Water Resour. Manage., 23: 1763-1780. DOI: 10.1007/s11269-008-9351-8

Wood, S.H., A.D. Ziegler and T. Bundarnsin, 2008. Floodplain deposits, channel changes and riverbank stratigraphy of the Mekong River area at the 14th-Century city of Chiang Saen, Northern Thailand. Geomorphology, 101: 510-523. DOI: 10.1016/j.geomorph.2007.04.030
Zhai, H.J., B.S. Cui, B. Hu and K.J. Zhang, 2010. Prediction of river ecological integrity after cascade hydropower dam construction on the mainstream of rivers in Longitudinal Range-Gorge Region (LRGR), China. Ecol. Eng., 36: 361-372. DOI: 10.1016/j.ecoleng.2009.10.002

Zhai, H.J., B.S. Cui, B. Hu, G.L. Wei and S.L. Liu, 2007. Regional ecosystem changes under different cascade hydropower dam construction scenarios in the LRGR. Chinese Sci. Bull., 52: 106-114. DOI: 10.1007/s11434-007-7016-2 